\title{
A GAZDASÁGI SZERVEZETEK SZEREPE A KÖZÖSSÉGI FEJLESZTÉSEK FINANSZÍROZẢSÁBAN
}

\section{(Public-Private Partnerships in Financing Public Services) LÁSZLÓ MÁRIA}

\author{
Kiindulópontok - elméleti alapok \\ (A közjótól a kooperatív városmenedzsmentig)
}

Az össztársadalmi és/vagy a gazdálkodó szervezetek által történỏ finanszírozása a közösségi funkcióknak és fejlesztéseknek; a gazdasági kapcsolatok olyan rendszerét hozza létre, mely meghatározza a gazdasági szemléletet és a gazdasági cselekvés motivációit egyaránt.

A közjó elmélete alapján a közösségi funkciók finanszirozása és az ilyen irányú szuikségletek kielégítése az egész társadalom ügye, össztársadalmi érdek, amelyröl alapvetỏen az államnak kell gondoskodni. Az állam által történö finanszírozás eszközrendszerében ez esetben a központi költségvetés a meghatározó. A központi kőltségvetési támogatás és a központi adók (pl. nyereség-adó, ÁFA, stb.), valamint az egyéb állami bevételek (pl. szerencsejátékok, totó-lottó haszna), illetve ezen központi bevételek célirányos átengedése és felhasználása a közösségi funkciók és fejlesztések finanszírozásában a domináns tényező.

Maga az állami támogatás is lehet közvetlen és kőzvetett. Utóbbi esetben az állam bizonyos bevételéről lemond a közösségi funkciók finanszírozása céljából (pl. adóbevételek egy részének átengedése vagy a központi költségvetésböl elkülönített pénzalapokba történő forrás átengedés). A forrás átengedés és forrás átcsoportosítás különböző technikáinak alkalmazása eltérỏ érdekviszonyokat érint, a központi szervek kapcsolatrendszerében és a vállalatok, illetve a fogyasztók viszonyrendszerében is ( $\mathrm{pl}$. a beszedett adók átengedése, pántlikázása, pénzalapok támogatása, stb.) más hatásokat vált ki a kủlönbözó gazdasági szereplök esetében, mint az adókedvezmények alkalmazása vagy a verseny semlegesség megsértése.

A gazdálkodó szervezetek szerepe mintegy kủlsődleges támogatóként jelenik meg azon elméleti kiindulópontot figyelembe véve, hogy mindenki vegyen részt a közjó finanszírozásában. Lényeges az állam (adópolitika) és a vállalati támogatás aránya, melyben a központi adórendszer és az állam szerepvállalása, valamint a társadalmi elvárások általában meghatározzák a gazdasági szervezetek magatartását, a közösségi funkciók finanszírozásában való részvételüket is.

A közjó elmélete az alkalmazott gazdaságpolitikai gyakorlatban gazdasági rendszerenként és országonként eltérö módon jelenik meg. Mindez nemcsak az állam és a piac viszonyának alakulására, az állam és a gazdasági szervezetek viszonyára, hanem a non-profit szektor kialakulására és fejlődésére is hatással volt, kủlönösen érintve a szociálpolitika, oktatás, egészségügy, kultúra, ágazati finanszírozás kérdéseit. 
A világgazdaságban a gazdasági problémák és a gazdasági válságok egyre inkább elötérbe helyezték a források pluralitásán nyugvó, több forrásból származó finanszirozási megoldásokat, ahol is a gazdaság minden szereplöje egymás mellett és a partnerség elve alapjản részt vállal a közösségi funkciók és fejlesztések finanszírozásában. Természetesen Magyarországon és a kelet - közép-európaj országokban ennek a feltételrendszere a rendszerváltással, a gazdaság sokszektorúvá válásával teremtődött meg.

A közjó elmélete alapján a gazdasági szervezetek elsödlegesen, mint piaci szereplök kapcsolódnak a közösségi funkciók finanszírozásába - a költségvetésbe befizetett adóikon keresztül vagy a vállalati támogatások révén, mintegy külsö szereplöként. Nyilvánvaló, ez esetben is fontos, hogy valamilyen gazdasági érdek, társadalmi elvárás, stb. motiváló eróként megjelenjen és a különbözỏ gazdasági szereplỏk cselekvése integrált folyamatként realizálódjon.

Az emberi töke elmélete az ossztársadalmi finanszírozás azon sajátos formáit helyezi a közösségi funkciók finanszírozásának középpontjába, amikor a gazdálkodó szervezetek érdeke a munkaeró újratermelését és a foglalkoztatott munkaeró minóségét, színvonalát, kvalitásait érinti (pl. oktatás, kultúra, egészségügy, szakképzés - általános müveltség, innovációs készség, stb.).

E megközelítés alapján beszélhetünk a vállalati szociálpolitika, a munkahelyi képzés és müvelődés és más területek vállalati támogatásáról, mely megjelenhet önálló vállalati intézményrendszerek formájában vagy a vállalatok által fizetett járulékok, céladók alkalmazása révén. Ilyen funkciót tölt be pl. a szakképzési hozzájárulás, müszaki-fejlesztési hozzájárulás.

A gyakorlat az emberi tóke elméleti kiindulópontja alapján is sokféle és változatos formákat hozott és hozhat létre a közösségi funkciók és fejlesztések finanszírozása terén, elsódleges célként szem elött tartva a munkaeró szinvonalának növelését. Ide sorolhatjuk azokat az egyưttmúködési megállapodásokat is, melyek a vállalatok és a helyi önkormányzatok között jöttek létre, igy pl. intézmények múködtetésére vonatkozóan és a költségek sajátos megosztását vagy átvállalását alkalmazva.

A gazdálkodó szervezetek, fóként az uzleti/profit szervezetek részvétele sok tényezőtől fủgg, de fơleg az adórendszer és a gazdaságj - társadalmi környezet által determinált, ideértve az állam - piac viszonyát és a helyi kapcsolatrendszerek alakulását is.

A költség-haszon elméletek és a különbözö jövedelmezőségi elméletek megkơzelitési módjait e tanulmánynak nem célja részletezni. Ez a megkőzelítési mód gyakorlatilag a nyereség/profit újraelosztásának, átcsoportosításának kủlönbözỏ technikáit érinti, az ágazatok közötti és az egyes ágazatokon belüli eltérỏ jövedelmezőségi lehetőségeket veszi figyelembe az alkalmazott finanszírozási megoldásoknál.

Különösen érvényesülhetnek ezek a technikák a kultúra finanszírozásánál. Ilyen eszközök, pl. a járulékok kivetése, árbevétel vagy nyereség arányában kivetett hozzájárulások, stb. alkalmazása, de esetenként elöfordulnak a megegyezésen alapuló jövedelem átcsoportosítások is, vagy a feladatok és programok közös egyuittmüködésen nyugvó finanszirozása is. Jól müködtethető ilyen együttmúködés kistelepulléseken a vendéglátóipari egységek és a mủvelödési ház, illetve az önkormányzatok megegyezése alapján. 
A környezetelméleti megközelitések a közösségi funkciók - különösképpen a külső gazdasági hatások (externáliák) finanszírozásánál kapnak nagyobb hangsúlyt, mint elméleti kiindulópontok. Azáltal, hogy új értelmezést kap és tágul a vállalkozások környezete (technikai, ökonómiai, szociális, ökológiai környezete) - a fogyasztói elvárások kapnak nagyobb szerepet a gazdasági szervezetek magatartását és cselekvési motivációit illetỏen.

Ez a megközelítési mód találkozik azokkal a vállalat elméleti megközelítésekkel, melyek a vállalkozások szükebb és tágabb környezetét veszik alapul. A vállalat, mint szervezet, és mint cselekvő személyiség, illetve a döntésekben részt vevők szerepének vizsgálatával a témánk szempontjából kiemelhetö kérdések:

- a vállalatok, gazdasági szervezetek külső és belső kapcsolatrendszerei,

- a kollektívák szerepe és az identitás (helyi és regionális szinten),

- külsö környezet, mely a cselekvés szükségletét váltja ki,

- helyi hatalomban való részvétel, presztizs szerepének értéke,

- a gazdasági tevékenységek nem gazdasági következményei,

- a tranzakciós költségek növekedése,

- a jövö orientált gazdasági szemlélet illetve felkészülés a jövöbeli lehetöségekre különbözö konfliktusokra,

- az információ szerepének és igényének növekedése,

- elörelátási képességek növekedése,

- a gazdasági etika értelmezése, hatásai,

- a racionalitás és a forrásallokáció lehetöségei,

- a fogyasztásban a választási lehetőségek bövülése,

- a környezet tágabb értelmezésének átértékelődése, stb.

A felsorolt szempontok - melyek sorát folytathatnánk - rámutatnak arra, hogy a gazdasági szervezetek szempontjából a környezet nem csak eszköz a célok eléréséhez, hanem a kapcsolatban álló emberek, szervezetek, intézmények fontosak és azok véleménye is egyre fontosabbá válik a gazdasági szervezetek és azok környezetében lévő más szervezetek, intézmények és egyének, illetve csoportok együttmüködésében, a helyi és a vállalati politika formálásában.

A helyi kapcsolatrendszereket meghatározó tényezők és folyamatok között vannak olyanok, amelyek kitágítják a teret (pl. tömegtermelés, szállítás, stb.) és vannak, amelyek szükítik azt (pl. helyben igénybe vehető szolgáltatások, stb.).

A gazdasági szervezetek - saját helyzetük optimalizálása érdekében is részt vesznek a társadalmi optimum és az általános gazdasági egyensúly létrehozásában, a gazdasági funkcióik realizálása során vagy éppen a lobby-tevékenységeik révén.

\section{A marketingszemléletũ településfejlesztés}

A helyi együttmüködést ösztönzi a telepưléseken - különösképpen a városokban az olyan új szemléletủ döntési folyamat, melynek során jellemzövé válik:

- a társadalmi, gazdasági és szociális érdekcsoportok bevonása az öket érintő projektek kidolgozásába,

- a település minden érdekcsoportjának tájékoztatása, kommunikációs csatornák kiépitése,

- a településszintü erőforrás menedzsment és a helyi kooperáció. 
A marketing szemléletú telepủlésfejlesztés célja a hely elönyeinek termékké alakítása (várostermék, helytermék) - ahol is szoros és intenzív az egyưttmúködés az állami, az önkormányzati és a magánszféra között.

A kooperatív városmenedzsment tudatos választását tapasztalhattuk pl. Köln, London esetében. Magyarországon úgy tünik, hogy a külföldi tőke és a vegyes vállalatok, de a nemzetkỏzi pályázatok elvárásai is a kooperativ városmenedzsment irányvonalát ösztönzik és a projektorientált városfejlesztéshez kapcsolnak inkább fejlesztési forrásokat. A nemzetközi tapasztalatok is azt mutatják, hogy ez esetben találhatók meg leginkább az ipari és technológiai parkok, az innovációs központok és az új technológiák, éppen a gazdasági szervezetek támogatásával és közösen alakítanak ki kulturális, kutatási, rendezvényi funkciókat az adott településen és annak térségében is. A fejlesztési pénzek és az állam részvétele is kooperatívvá tehető.

Magyarországon még csak kezdeti jeleit találhatjuk a marketing szemléletü településfejlesztésnek és a kooperativ városmenedzsmentnek. Az igény különösen a városfejlesztési koncepciók és a marketingkoncepciók készítésének folyamatában fogalmazódott meg a nagyvárosainkban.

Vannak városok itthon és külföldön, melyek az ún. reklám-és imázspolitikát választották, ahol is a kereskedelem, a belváros bevásárlási és szolgáltatási funkciók értékesitését célozták meg. Ez esetben a gazdasági szervezetekkel az együttmúködés ezekben az ágazatokban jóval intenzívebb, mint a többi ágazatban. Valójában ilyenkor a keresletösztönzés és a beruházások befolyásolása áll a középpontban (pl. Hamburg, Budapest). E módszer nem igen alkalmas a közfeladatoknak és a szociális problémáknak a megoldására.

Más esetekben (pl. Székesfehérvár) azzal találkozunk, hogy az önkormányzat a helyi gazdasági szervezetek bevonásával is a város eladását menedzseli, ahol is a termék a város és annak minden közszolgáltatása.

Láthatjuk, hogy a marketing szemléletű településfejlesztés különbơző irányzata a gazdasági szervezetek célcsoportján belül más - más csoportokat preferál, esetenként az együttmúködés beszükülhet egy - egy konkrét, meghatározó gazdasági szervezetre, a helyi politika szempontjából legfontosabb gazdasági aktorra, nagyvállalatra, egy-egy ágazat képviselöjére.

Szélesebb körủ az együttmủködés a szolgáltatásmarketing alkalmazása esetében a helyi gazdasági szervezetekkel, amikor is a szolgáltatások tervezésébe az önkormányzat, mint semleges moderátor vonja be a cégeket, fóként a húzóágazatok képviselöit (Göteborg, Magdeburg és potenciálisan Györ lehet erre példa).

A gazdasági szervezetek bevonása és a helyi egyưttmüködés mechanizmusának kialakítása időigényes és költséges folyamat, fóképpen a magas tranzakciós költségek miatt. Azáltal viszont, hogy a településpolitika, a városfejlesztési koncepció mögött létrejơn/létrejöhet a helyi konszenzus, nagyobb a megvalósítás társadalmi bázisa, és ezáltal a realizálás és a megtérülés esélye is. Azok, akik részt vesznek a helyi feladatok alakításában, a fejlesztési koncepció kidolgozásában, jobban magukénak érzik a település ügyeit és a fejlesztéseket, mert tudják, hogy igényeik (kivánságaik) kerültek ott megfogalmazásra. 
A gazdasági szervezetek részvétele fontos:

- a településidentitás és régióidentitás,

- a település-arculat,

- a településkultúra, magatartás,

- a település-kommunikáció szempontjából is.

Az együttmủködés sajátos területei:

- a városfejlesztési koncepció alakítása és végrehajtása,

- ötletek, szellemi bázis biztosítása,

- lobby tevékenység,

- forrás-szerzés és azok koncentrálása,

- a telepulés bemutatása (kiállításokon, vásárokon, konferenciákon és különbözö írott anyagokban, prospektusokban),

- személyes kapcsolatok és találkozások szervezése,

- együttmüködési megállapodások elökészítése és realizálása,

- kiadvány politika alakítása,

- kódrendszer létrehozása, stb.

E sorba illeszthetök a több funkciót biztositó szponzorálási tevékenységek.

Empirikus vizsgálatok azt mutatják, hogy általában a gazdasági szervezetek mérete és a költségvetési korlátaik puha- vagy kemény jellege a meghatározó és kisebb mértékben játszik szerepet a jövedelmezőség, az elért nyereség (bár egyre inkább összekapcsolódnak, összefưggésben állnak a különböző tényezők).

A baranyai megyeszékhely nagyvállalatainál gyakorlatilag napi bontásban mérik a beérkezö támogatási kérelmeket (napi átlagban 10-15 kérelmet, évi átlagban több mint 3000) írásbeli vagy személyes megkeresést említettek a vállalatvezetök az interjúk során. Ma már jellemzö, hogy a nagyobb vállalatok, ahol föként a reklámköltségeik terhére szponzorálnak, intézményesített vagy informális csatornákon keresztül kialakítanak egy sajátos munkamegosztást is, a nagy szponzorok kőzőtt végbemegy egy sajátos funkciómegosztás (oktatás, sport, kultúra, egészségügy finanszírozását illetően).

$\mathrm{Az}$ infrastruktúra fejlesztés, közmüvesítés terén viszont az önkormányzatoktól elvárják, hogy oldja meg a feladatot, adottságként, elöfeltételként kezelik ezek meglétét.

A klasszikus szponzori tevékenység (sportklubok, fesztiválok és rendezvények támogatása, stb.) mellett a gazdasági szervezetek a helyi iparüzési adó meghatározott \%-áról szóló rendelkezést is a szponzori tevékenységhez sorolják, és szigorúan számon tartják és nyilvánosságra is hozzák, hogy ki az általuk megnevezett kedvezményezett és ez esetben mekkora összegröl van szó egy-egy pl. kulturális intézmény, színház esetében.

A rendszeres, klasszikus szponzori tevékenység és az iparüzési adó meghatározott \%-áról szóló rendelkezés mellett gyakorlatilag minden cég külön kezelte a különböző ún. jótékonysági támogatásokat (pl. óvodák támogatása gyerekjátékok vásárlásához, iskolai kirándulások és rendezvények pénzeszközökkel történő segitése, egy-egy városi szintủ rendezvény dijazottjainak elismeréséhez nyújtott pénzbeli vagy természetbeni támogatás, stb.) Ezek eseti támogatások és reklámhatásuk, nyilvánosságuk is lényegesen kisebb körben érzékelhetö, mint az elöbbi eszkőzrendszerek esetében. Tapasztalható, hogy a gazdasági szervezetek is keresik a lehetöségeket, az új formákat e téren is. Van olyan vállalat, amelyik pl. képzőmủvészeti pályázat kiirását tervezi, melynek anyagát több kiállításon bemutatnák majd. 
Az oktatás, de még inkább az egészségugy támogatásának projekt-orientált jellege növekszik, mivel a vállalatok akkor támogatnak inkább, ha konkrét berendezésre van igény és annak a funkciója is egyértelmüen megnevezett. (Pécsett pl. mentóállomásra vagy klinikákra és kórházakba berendezés, diagnosztikai központ, hajléktalanok háza, stb.).

A gazdasági szervezetek szempontjából a kơzösségi funkciók támogatása és a fejlesztések finanszírozása relatíve olcsóbb reklám, mint pl. a fizetett hirdetések a tömegkommunikációban. Ugyanakkor ennek ellenére jól érzékelhető, hogy ennél tőbbról van szó helyi szinten (pl. presztízs, társadalmi elvárás és elismertség, közősségi kapcsolatrendszer, fogyasztói bázis és a fogyasztókkal, politikával való kapcsolat, stb.).

A nagyobb vállalatok a vállalatpolitika céljai közơtt a szponzorálás és a kủlönböző támogatások prioritás-sorrendjét is meghatározzák. Kedvezỏbb a támogatásokhoz való viszonyulás a fejlesztések esetében, a mükődtetés finanszírozását és annak támogatását (fơként az önkormányzati intézmények esetében) kevésbé szívesen vállalják.

A gazdasági szervezetek kőzőtt a szponzorálás bármelyik formáját tekintve sajátos helyzetben vannak az önkormányzatok tulajdonában lévố cégek (Kft., Rt. formájában múkődổ gazdasági társaságok). Tapasztalataink szerint e körben még inkább, mint máshol az elsó számú vezetók beállítottsága és az önkormányzat választott vezetỏivel való személyes kapcsolata a meghatározó, ha az alaptevékenységen kívưli helyi kơzösségi funkciók finanszírozásáról van szó.

Vannak olyan cégek, amelyek hasonlóan a magánvállalatokhoz, szponzorálnak rendezvényeket, támogatnak alapítványokat és ezekről saját hatáskörben, ơnállóan is döntenek. Másoknál a vezető véleménye az, hogy csak akkor hajlandó rendezvényeket szponzorálni, ha a tulajdonos ónkormányzat (a polgármester) írásban utasítja erre. Talán ez a példa jól illusztrálja a témával kapcsolatos helyi konfliktusokat is.

A gazdasági szervezetek a helyi kapcsolatrendszereken keresztuil vesznek részt és kapcsolódnak a közősségi funkciók finanszírozásához.

A helyi kapcsolatrendszerek jellemzói lehetnek:

- Önkéntes adakozás, eseti támogatások esetében, formalizált vagy nem formalizált módon. Ez esetekben a gazdasági szervezetek elsődlegesen helyi társadalmi elvárásoknak kívánnak eleget tenni.

- Átadott, átvett pénzeszközök formájában, mely leginkább a rendszeres kapcsolatokra jellemzó és fejlesztések finanszírozásánál is alkalmazható megoldás.

- Egyulttmúkoðdési megállapodásokon nyugvó rendszeres kapcsolatokban, ahol már a gazdasági érdekek inkább elötérbe kerülnek, de a kölcsönősségi viszonyok, a reciprocitási kapcsolatok is jellemzőek lehetnek.

- A helyi adórendszeren keresztul érvényesủló kapcsolatokban, igy a már említett iparúzési adó meghatározott \%-áról szóló rendelkezés alkalmazásával, az érdekeltségi viszonyok és az osszőnzési célok realizálásával.

A gazdasági szervezetek a kơzösségi funkciók és fejlesztések finanszírozásában az államháztartási kapcsolatokon keresztül is részt vesznek, ahol az államháztartás minden alrendszerével valamilyen formában kapcsolatba kerülnek. 
Bár e tanulmányban az államháztartási kapcsolatokkal és az államháztartási reform kérdéseivel nem foglalkozom, de mindenképen fontosnak tartom megemlíteni, hogy az államháztartás és az alrendszerek közötti kapcsolatrendszer a témánk szempontjából sajátos módon meghatározza a gazdasági szervezetek viszonyulását a közösségi funkciók finanszírozását illetően. Fontos, hogy a feladat felelösség - finanszírozás összhangja megvalósuljon a reform során.

Ösztönzötté a helyi együttmükődés akkor válik, ha a reform megteremti a helyi források feltárásához kapcsolódó érdekeltség és az állami támogatás rendszerének konzisztens rendszerét. Az államháztartási kapcsolatok sajátosságait az önkormányzatok költségvetési kapcsolatai mutatják. 1996-ban a müködési célú átvett pénzeszközök 94,05\%-a az államháztartáson belülröl átvett pénzeszköz, melyen belül meghatározó a TB alapok és kezelöiktől átvett pénzeszközök nagysága és aránya. Ezek súlya az összes müködési célra átvett pénzeszközökön belül 82,92\% volt. Azt is tapasztalhattuk vizsgálataink során, hogy 1993-1996 közötti idöszakban az elkülönitett állami pénzalapoktól és kezelőiktöl átvett müködési célú pénzeszköz növekedett a legnagyobb arányban (535,02\%-ra), növelve ezzel részarányát 2,25\%-ról 7,10\%-ra. (1. táblázat)

\section{TÁBLÁZAT}

Önkormányzatok mũködési célra átvett pénzeszközei Magyarországon az 1993 és 1996 években

(Financial Resoruces to Cover Operation Costs of Local Governments 1993, 1996)

\begin{tabular}{|c|c|c|c|c|c|}
\hline \multirow[b]{2}{*}{ Megnevezés } & \multicolumn{2}{|c|}{1993} & \multicolumn{2}{|c|}{1996} & \multirow{2}{*}{$\begin{array}{l}\text { Váitozás } \\
\% \text { \%-a }\end{array}$} \\
\hline & ezer Ft & Megoszlás & ezer $\mathrm{Ft}$ & Megoszlás & \\
\hline Önkormányzaton belül & 42.012 & 0,04 & 0 & 0 & . \\
\hline $\begin{array}{l}\text { Más önk. költségvetési } \\
\text { szervétől }\end{array}$ & 520.039 & 0,50 & 0 & 0 & . \\
\hline $\begin{array}{l}\text { Önkormányzati intézm. } \\
\text { fenntartó társuláshoz }\end{array}$ & 0 & 0 & 0 & 0 & . \\
\hline $\begin{array}{l}\text { Közös létesitmény } \\
\text { fenntartásához }\end{array}$ & 0 & 0 & 0 & 0 & . \\
\hline $\begin{array}{l}\text { Fejezettől kp-i } \\
\text { költségvetési szervtől }\end{array}$ & 4.195 .206 & 4,00 & 7.213 .704 & 4,03 & 171,95 \\
\hline $\begin{array}{l}\text { TB alapoktól és } \\
\text { kezelöitől }\end{array}$ & 91.624 .678 & 87,37 & 148.416 .752 & 82,92 & 161,98 \\
\hline $\begin{array}{l}\text { Elkülön. állami } \\
\text { pénzalapoktól }\end{array}$ & 2.374 .449 & 2,26 & 12.703 .736 & 7,10 & 535,02 \\
\hline $\begin{array}{l}\text { Mũködési célra átvett } \\
\text { pénzeszkoöz } \\
\text { államháztartáson belül }\end{array}$ & 6.110 .073 & 5,83 & 10.650 .575 & 5,95 & 174,31 \\
\hline $\begin{array}{l}\text { Müködési célra átvett } \\
\text { pénzeszkőz összesen }\end{array}$ & 104.866 .457 & 100,00 & 178.984 .767 & 100,00 & 170,68 \\
\hline
\end{tabular}

Forrás: Ország osszesen. Az onkormányzatok ellátottságának fôbb pénzủgyi és naturális mutatói, $\mathrm{BM}, 1993$. Az onkormányzatok föbb pénzägyi, ellátottsági mutatói és ingatlanvagyon kataszter adatai BM, 1996. 
$\mathrm{Az}$ önkormányzatok felhalmozási célra átvett pénzeszközeinél viszont a vizsgált időszakban jelentőségét tekintve nagyobb arányú volt az államháztartáson kívülröl átvett felhalmozási pénzeszközök súlya, mely 59,77\%-ról 58,39\%-ra változott (kismértékben csökkent), míg az államháztartáson belülröl átvett pénzeszközök aránya 40,23\%-ról 41,61\%-ra változott. (2. táblázat)

\section{TÁBLÁZAT}

Önkormányzatok felhalmozási célra átvett pénzeszközei Magyarországon az 1993. és 1996. években

(Financial Resources of Local Governments for Accumulation 1993, 1996)

\begin{tabular}{|c|c|c|c|c|c|}
\hline \multirow{2}{*}{ Megnevezés } & \multicolumn{2}{|c|}{1993} & \multicolumn{2}{|c|}{1996} & \multirow{2}{*}{$\begin{array}{l}\text { Változás } \\
\text { \%-a }\end{array}$} \\
\hline & ezer Ft & $\begin{array}{l}\text { Meg- } \\
\text { oszlás }\end{array}$ & ezer $\mathrm{Ft}$ & $\begin{array}{l}\text { Meg- } \\
\text { oszlás }\end{array}$ & \\
\hline Önkormányzaton belül & 326.780 & 2,02 & 0 & & \\
\hline $\begin{array}{l}\text { Más önk. kőltségvetési } \\
\text { szervtől }\end{array}$ & 37.009 & 0,23 & 451.676 & 1,59 & $1.217,75$ \\
\hline $\begin{array}{l}\text { Fejezettől, kp-i } \\
\text { költségvetési szervtől }\end{array}$ & 1.474 .497 & 9,11 & 7.144 .177 & 25,15 & 484,52 \\
\hline $\begin{array}{l}\text { TB alapoktól és } \\
\text { kezelóitől }\end{array}$ & 6.025 & 0,03 & 74.564 & 0,26 & $1.237,58$ \\
\hline $\begin{array}{l}\text { Elkủl. állami } \\
\text { pénzalapoktól és } \\
\text { kezelöitől }\end{array}$ & 4.670 .313 & 28,84 & 4.149 .238 & 14,61 & 88,84 \\
\hline $\begin{array}{l}\text { Felhalmozási célra átvett } \\
\text { pénzeszközők } \\
\text { államháztartáson } \\
\text { belül összesen }\end{array}$ & 6.514 .624 & 40,23 & $11.819,655$ & 41,61 & 181,43 \\
\hline $\begin{array}{l}\text { Felhalmozási célra átvett } \\
\text { pénzeszközők } \\
\text { államháztartáson kivuulről }\end{array}$ & 9679471 & 59,77 & 16.582 .034 & 58,39 & 171,31 \\
\hline $\begin{array}{l}\text { Felhalmozási célra átvett } \\
\text { pénzeszközök összesen }\end{array}$ & 16194095 & 100,00 & 28.401 .689 & 100,00 & 175,38 \\
\hline
\end{tabular}

Forrás: Ország osszesen. Az önkormányzatok ellátottságának fóbb pénzủgyi és naturális mutatói BM, 1993. Az önkormányzatok föbb pénzủgyi, ellătottsági mutatói és ingatlanvagyon kataszter adatai BM, 1996.

A múködési célra és a felhalmozási célra átvett pénzeszközök államháztartáson kívülröl származó részarányának növekedése arra utal, hogy növekedett az önkormányzati szféra helyi, illetve államháztartáson kívüli kapcsolatrendszere (ha nem is a kivánt mértékben).

Bővültek azok a pénzügyi és egyéb kapcsolatok, melyek a gazdasági szférával és az állampolgári szerveződésekkel, a civil társadalommal kötik össze az önkormányzatok gazdálkodását.

A településszintủ kapcsolatrendszerekben a helyi közősség, annak értékrendszerei, értékorientációi, a tradíciók és az emocionális gazdasági cselekvés lényegesen nagyobb arányban - de településenként eltéróen jelennek meg, mint a makrogazdasági folyamatokban vagy a profitszférában, ahol természetesen a célorientált gazdasági cselekvési motivációk lényegesen eröteljesebben hatnak. 
Azokon a településeken alakultak a helyi kapcsolatok intenzíven, ahol a civil szféra szerveződése és ezáltal ösztönző szerepe kedvezőbb volt. Az elmúlt idöszakban az, hogy a települési önkormányzatok költségvetése elsősorban a müködést és nem a fejlesztést szolgálta/szolgálja nemcsak a településfejlesztés, hanem a helyi társadalmi aktivitás szempontjából is gondot jelent. Megmutatkozik mindez a helyi források feltárásánál, a helyi kezdeményezések és a civil társadalom, valamint a helyi gazdasági szervezetek magatartásánál, cselekvési motivációinál is.

A helyi gazdaságpolitika alakításánál és a települési feladatok finanszírozásánál a finanszírozási források alapvetően függnek az erőforrásoktól, melyek korlátozottan és szükősen állnak rendelkezésre egy adott gazdálkodási mód és gazdasági struktúra mellett. Az erőforrások feltárása éppen ezért jelenti az új eröforrások kutatását, de a meglévő erőforrásokkal történő új, illetve más gazdálkodási mód és gazdasági szervezet, sőt más szervezeti keretek mellett történő gazdálkodást is. A szükséges változásokhoz, a szemléletváltáshoz az ágazati szemlélet helyett a területi szemlélet szükségessége jelenik meg a települések költségvetésének és a helyi kapcsolatok alakitásának tervezésénél is.

A gazdasági szervezetek bevonása a közösségi funkciók finanszírozásába alapvetően a meggyőzésen és a közös elhatározáson alapulhat, amelyek a választási lehetöségek bővitését és azok közötti alternatív választási lehetöségek kimunkálását is szükségessé teszi a folyamatos tárgyalások és kapcsolattartás segítségével. A gazdasági szervezetek ezt igénylik is a helyi önkormányzatoktól, mely alapján a szolgáltatásszervezés és ellátás is hatékonyabbá tehető a jövöben. A közös elhatározás, az együttmúködési mechanizmus és annak intézményesítése a feladatmegosztás és a forrásbővítés mellett a differenciált szükséglet kielégítést is elősegíti. Hatékony eszköz lehet, ha a már eddig megkötött együttműködési megállapodások lehetőségeit hasznosítják a településszinteken, de az új együttmüködési megállapodások megkötését is igénylik a gazdasági szervezetek.

A helyi együttmúködés és a gazdálkodó szervezetek részvétele a közösségi funkciók finanszírozásában jól tükrözik azokat a változásokat, melyek az önkormányzatiság eddigi időszakában végbementek és meghatározóak a gazdaság és a település viszonyában:

- a piacgazdaság intézmény- és szabályozórendszerének alakulását,

- a sokszektorú gazdaság létrejöttét, a tulajdonformák és szervezeti formák átalakulását, megváltozását,

- a privatizáció és az általa kialakult forrás- és jövedelemelosztás, valamint a vagyonelosztás módosulását,

- a gazdaság szerkezetének és méretstruktúrájának változását,

- a gazdaság térbeli rendjének átalakulását,

- a területi különbségek nyílt felszínre kerülését,

- az erőforrások és a környezet átértékelödését, az erőforrások közötti arányok változását,

- a foglalkoztatottság és munkanélküliség gazdasági és társadalmi konfliktusainak élezödését,

- a szociálpolitika és a szegénység problémáit,

- a jövedelemosztásban keletkezett differenciálódás növekedését, stb. 


\section{Településfinanszirozás - területfejlesztés - partnerség}

Az önkormányzati törvény, a rendszerváltás első törvẻnyei között került elfogadásra, amikor még a piacgazdaság, a sokszektorúság intézményei és szervezetei sem alakultak ki teljesen. Az 1994. évi törvénymódosítás, mely az 19901994. közötti időszak gyakorlati tapasztalatai alapján született, az önkormányzatok gazdasági eszközrendszerével kapcsolatos kérdések hiányosságait és konfliktusait teljes mértékben nem tudta feloldani. A problémák győkereinek egy jelentős része abból származik, hogy az államháztartás reformja elhúzódott, alapvetően nem tisztázott az államháztartás alrendszerei közötti munkamegosztás és finanszírozás megosztás, mely leginkább érinti az állam és az önkormányzatok közőtti viszonyt, de természetesen az államháztartás más alrendszerei közötti kapcsolatot is. A szabályozás jelentős mértékben befolyásolja az önkormányzati szféra saját bevételi lehetöségeit, amellett, hogy fennmaradt a finanszírozásban a túlzott mértékü makro meghatározottság a lakosság és a gazdasági szféra központi adóterhei, a jövedelemelosztás, bér- és szociálpolitika, stb. az önkormányzatok saját bevételének növelési lehetőségeit korlátozzák és a müködtetés, mint a bevételnövelés elsődleges célja is korlátozza a helyi valódi érdekeltség megteremtését.

Az OTKA 7047. sz. Az önkormányzatok gazdasági eszközrendszere c. kutatási téma keretében folytatott vizsgálataink során (1993-1996) is tapasztalhattuk, hogy olyan idöszakban, amikor a többlet teher nem kapcsolódik mozgósító erejú célhoz, fejlesztéshez, lényegesen kisebb a helyi kapcsolatrendszerek szerepe a forrásfeltárás és forrásbövités folyamatában a helyi gazdasági szereplök és a lakosság aktivizálásában. A müködést messze alulfinanszírozó normativ központi támogatások, illetve a célhoz kötơtt fejlesztési hozzájárulások olyan determinációt jelentenek, amelyek mellett a helyi költségvetés és adórendszer nem képes a helyi ơnállóság preferenciáit érvényesíteni. Az eltelt időszak lényeges elörelépést teremtett ugyan az önkormányzati ơnállóság és jogegyenlöség szempontjából, de tơbb hátránya a helyi kapcsolatrendszerek fejlödését és az ơnkormányzatok egyưttmúkődését is fékezi, ugyanakkor megmerevíti a fennálló intézményi struktúrát és akadályozza új ellátási szervezeti formák és szereplők megjelenését a lakossági ellátásban a közszolgáltatások területén.

A központositott újraelosztás mértéke és aránya nem csak azért sérti az ơnkormányzati önállóságot, mert erős determinizmust gyakorol az önkormányzatok múködtetési és fejlesztési döntéseire, hanem azért is, mert csökkenti az önkormányzatok bevételi érdekeltségét, rontva ezzel a helyi gazdasági aktivitásukat is. Miután kevés a szabad, saját fejlesztési forrás, az oonkormányzatok döntő tơbbsége olyan fejlesztésekbe fog, amelyet állami cél- vagy egyéb jellegủ támogatással lehet finanszírozni. Ez a szempont elnyom minden más mérlegelést, a helyi szulkségletek és igények figyelembe vételét, a hosszú távú szemléletet és a tervszerüséget. Mivel azonban a fejlesztési célok kiválasztása külsődleges impulzusok alapján történik, így a helyi forrásszerzésben a transzaktivitás lehetösége eleve leszükül. Ha viszont az önkormányzat nem olyan fejlesztésekbe fog, amelyben kơzvetlen módon megjelenik a helyi társadalom és a helyi gazdaság érdekeltsége, akkor sem helyi adóval, sem más formában nem számíthat helyi támogatásra. Tehát a központosított elosztás és az alkalmazott mechanizmus legnagyobb hátránya, hogy nem ösztönzi az önkormányzatokat sem tranzaktív 
gazdálkodásra. Mindez azért sajnálatos, mert jelentős helyi forrásoktól esnek el az önkormányzatok, mert nem kapcsolható össze, vagy csak véletlenszerủen az önkormányzatok, az állam, a helyi társadalom és a gazdaság érdeke, érdekeltsége.

Az önkormányzatok gazdálkodását, a költségvetés bevételi és kiadási szerkezetét elemezve is azt tapasztalhatjuk, hogy ezekben is tükrözödnek mindazok a gazdasági és társadalmi különbségek, melyek a területi és a települési különbségeket is meghatározzák, sôt sok esetben generálják is azokat.

Az önkormányzati költségvetési gazdálkodás a szándékok és elvek ellenére sem vezetett a települések és térségek különbségének csökkenéséhez, nem járult hozzá a települések és lakosai esélyegyenlőségének megteremtéséhez az önkormányzati gazdasági eszközrendszer oldaláról sem.

A területi különbségek jól illusztrálhatók a területi GDP adatokkal, melyek az adott térség jövedelemtermelö képességét is tükrözik. (3. táblázat).

$\mathrm{Az}$ egyes megyék helyzetét jelzi, hogy az önkormányzati gazdálkodás eddigi éveiben folyamatosan növekedett az ún. kedvezményezett települési kör, mely 1996-ban már az önkormányzatok 45\%-át érintette. (4. táblázat)

\section{TÁBLÁZAT}

A megyék fejlettségi szintje a bruttó hozzáadott érték (GDP) alapján, 1995 (Per capita GDP in the Counties, 1995)

\begin{tabular}{|c|c|c|c|c|c|c|}
\hline \multirow{4}{*}{ Megyék, fóváros } & \multicolumn{3}{|c|}{$\begin{array}{c}\text { Sorrend az egy före jutó } \\
\text { GDP alapián }\end{array}$} & \multirow{2}{*}{\multicolumn{3}{|c|}{ Egy före jutó bruttó hazai termék }} \\
\hline & \multicolumn{2}{|c|}{1994} & \multirow[t]{3}{*}{1995} & & & \\
\hline & \multirow{2}{*}{\multicolumn{2}{|c|}{$\begin{array}{c}\text { régi } \underset{\text { új }}{ } \\
\text { módszer szerint }\end{array}$}} & & \multirow[t]{2}{*}{ ezer Ft/fö } & az országos & a megyei \\
\hline & & & & & \multicolumn{2}{|c|}{ átlag \%-ában } \\
\hline Budapest & 1 & 1 & 1 & 970 & 178 & - \\
\hline Bács-Kiskun & 14 & 14 & 12 & 430 & 79 & 96 \\
\hline Baranya & 8 & 8 & 10 & 460 & 85 & 103 \\
\hline Békés & 10 & 12 & 17 & 413 & 76 & 93 \\
\hline Borsod-A.-Zemplén & 18 & 18 & 16 & 414 & 76 & 93 \\
\hline Csongrád & 7 & 5 & 6 & 520 & 96 & 117 \\
\hline Fejér & 4 & 4 & 4 & 535 & 98 & 120 \\
\hline Győr-Moson-Sopron & 2 & 2 & 2 & 575 & 106 & 129 \\
\hline Hajdú-Bihar & 9 & 9 & 14 & 417 & 77 & 94 \\
\hline Heves & 17 & 17 & 15 & 415 & 76 & 93 \\
\hline Jász-Nagykun-Szolnok & 12 & 13 & 13 & 422 & 78 & 95 \\
\hline Komárom-Esztergom & 11 & 10 & 8 & 481 & 88 & 108 \\
\hline Nógrád & 19 & 19 & 20 & 332 & 61 & 75 \\
\hline Pest & 16 & 16 & 18 & 388 & 71 & 87 \\
\hline Somogy & 15 & 15 & 11 & 434 & 80 & 97 \\
\hline $\begin{array}{l}\text { Szabolcs-Szatmár- } \\
\text { Bereg }\end{array}$ & 20 & 20 & 19 & 338 & 62 & 76 \\
\hline Tolna & 6 & 6 & 7 & 505 & 93 & 113 \\
\hline Vas & 3 & 3 & 3 & 574 & 106 & 129 \\
\hline Veszprém & 13 & 11 & 9 & 473 & 87 & 106 \\
\hline Zala & 5 & 7 & 5 & 522 & 96 & 117 \\
\hline
\end{tabular}

Forrás: A bruttó hazai termék (GDP) alakulása és területi megoszlása 1995-ben. Farkasházi LászlónéGether Istvánné dr. - dr. Vígh Judit Gazdaság és Statisztika 1997/3. 19-29. o. 


\section{TÁBLÁZAT}

A kedvezményezett települések megyénkénti összefoglaló adatai

(Complex Indices of Beneficiary Settlements)

\begin{tabular}{|c|c|c|c|c|c|c|}
\hline Megye & $\begin{array}{c}\text { A } \\
\text { települések } \\
\text { legkedvezỏt- } \\
\text { lenebb } \\
33,3 \% \text {-a }\end{array}$ & $\begin{array}{l}\text { A magas } \\
\text { munkanél- } \\
\text { küliségü } \\
\text { települések }\end{array}$ & $\begin{array}{c}\text { Az } \\
\text { elmaradott } \\
\text { és magas } \\
\text { munka- } \\
\text { nélküliségű } \\
\text { települések }\end{array}$ & \multicolumn{2}{|c|}{$\begin{array}{l}\text { Kedvezményezett } \\
\text { települések } \\
\text { száma aránya }\end{array}$} & $\begin{array}{c}\text { Összes } \\
\text { település }\end{array}$ \\
\hline Bács-Kiskun & 28 & 10 & 4 & 34 & 29 & 117 \\
\hline Baranya & 151 & 163 & 125 & 189 & 63 & 302 \\
\hline Békés & 29 & 32 & 25 & 36 & 48 & 75 \\
\hline $\begin{array}{l}\text { Borsod-Abaúj- } \\
\text { Zemplén }\end{array}$ & 198 & 241 & 166 & 273 & 77 & 355 \\
\hline Csongrád & 16 & 5 & 44 & 17 & 29 & 59 \\
\hline Fejér & 5 & 13 & 4 & 17 & 29 & 59 \\
\hline $\begin{array}{l}\text { Győr-Moson- } \\
\text { Sopron }\end{array}$ & 8 & 2 & 0 & 10 & 6 & 173 \\
\hline Hajdú-Bihar & 46 & 44 & 34 & 56 & 68 & 82 \\
\hline Heves & 29 & 38 & 18 & 49 & 42 & 118 \\
\hline $\begin{array}{l}\text { Jász-Nagykun- } \\
\text { Szolnok }\end{array}$ & 37 & 35 & 23 & 49 & 62 & 78 \\
\hline $\begin{array}{l}\text { Komárom- } \\
\text { Esztergom }\end{array}$ & 4 & 4 & 1 & 7 & 10 & 73 \\
\hline Nógrád & 42 & 65 & 34 & 73 & 57 & 127 \\
\hline Pest & 11 & 2 & 1 & 12 & 07 & 184 \\
\hline Somogy & 99 & 89 & 58 & 130 & 53 & 243 \\
\hline $\begin{array}{l}\text { Szabolcs- } \\
\text { Szatmár-Bereg }\end{array}$ & 154 & 181 & $\overline{142}$ & 193 & 85 & 228 \\
\hline Tolna & 38 & 38 & 25 & 51 & 47 & 108 \\
\hline Vas & 34 & 24 & 11 & 47 & 22 & 216 \\
\hline Veszprém & 39 & 53 & 25 & 67 & 30 & 224 \\
\hline Zala & 74 & 56 & 32 & 98 & 38 & 257 \\
\hline Osszesen & 1042 & 1095 & 732 & 1405 & 45 & 3125 \\
\hline
\end{tabular}

Forrás: A területfejlesztésre fordítható források decentralizálására alkalmazhatón eljárások. KSH, Bp., 1996. (Szerk. Faluvégi Albert)

Látható, hogy a legtöbb kedvezményezett település Borsod-Abaúj-Zemplén, Szabolcs-Szatmár-Bereg, Baranya és Somogy megyében van. (273, 193, 189, 130). Ezekben a megyékben a legmagasabb az egyben magas munkanélküliségü elmaradott települések száma is $(166,142,125,58)$. Nem éri el a 20-at ezzel szemben a kedvezményezett települések száma Komárom-Esztergom, Győr-MosonSopron, Pest, Fejér és Csongrád megyében. Ezekben a kedvezőbb helyzetü megyékben a munkanélküliség is alacsony. Györ-Moson-Sopron, Pest, KomáromEsztergom és Csongrád megyében 10 alatt van a kiemelten magas munkanélküliségü települések száma. A kedvezményezett települések száma jelzi azon népesség nagyságát és területi elhelyezkedését az országban, akiket sajátos módon érint az elmaradottság és ez a népességszám ma már több, mint 1 millió fö. Az elmúlt években bỏvült ugyan azon támogatások és többlettámogatások köre, mely a 
hátrányos helyzetben lévő településeket kivánta támogatni és elosztási mechanizmusával az elmúlt időszak területi és települési különbségeit próbálta csökkenteni. Valójában a leghátrányosabb települések kellő saját forrás hiányában nem tudtak forráshoz jutni, az önkormányzatok lehetöségei a költségvetési szerkezetük átalakitására és befolyásolására jelentős mértékü differenciákat mutatnak

A területfejlesztésröl és a területrendezésröl szóló 1996. évi XX1. tv. hatálybalépése után jelentős változások várhatók a területi különbségek kezelésének cél- és eszközrendszerét illetöen, melyek érintik a települések gazdálkodását és a térségi együttmüködéseket is. Ugyanakkor rövid- és középtávon az eddigi fejlödési pályák és a kialakult jövedelemtermelö képesség nagyobb meghatározottságot jelent az egyes térségekben és még inkább a településszinteken.

Témánk szempontjából a területfejlesztés vonatkozásában talán az egyik legfontosabb kérdés a partnerség elve, illetve annak érvényesülése.

A területfejlesztés szempontjából több értelemben is használja a szakirodalom e fogalmat, így pl. szintek közötti és szektorok közötti együttmüködésre egyaránt értelmezzük, de használhatjuk ezen belül az önkormányzati szféra és a gazdasági szervezetek közötti kapcsolatokra is.

A fogalom a területfejlesztésröl szóló törvény megjelenése után azért került elötérbe, mert a hagyományos területi döntéshozók, az önkormányzatok mellett létrejöttek a területfejlesztési tanácsok. Ezzel elvileg, de bizonyos vonatkozásokban gyakorlatilag is megkettózve az irányitást.

A szektorok közötti egyuittmükődés lehetősége a törvény által megteremtődik azáltal, hogy az önkormányzatok, illetve az állam és a gazdaság szereplöi (munkáltatók és munkavállalók) között intézményesíti is a törvény a tanácsban az együttmüködést. Ugyanakkor viszont nem vonja be közvetlenül a civil társadalmat a döntési folyamatokba és a tanácsokba.

A partnerségi szervezetek összetétele egyik szinten sem egyezik meg egymással és eltérő a kompetenciájuk is. Országos és megyei szinten is van választott közjogi szervezet és van partnerségi szervezet, de mégsem azonos funkció és kapcsolatrendszer alapján épült ki a két szinten a teruletfejlesztési döntéshozásban a szervezeti struktúra. (Pálné Kovács Ilona 1997)

Országos szinten: a partnerségi szervezet az Országos Területfejlesztési Tanács, konzultativ szereppel, nem tényleges döntési kompetenciával.

Megyei szinten: elfogadja a teruletfejlesztési koncepciót a Megyei Teruletfejlesztési Tanács.

Kistérségi szinten viszont már egyértelmủen megtörik a partnerség logikája. Kistérségi szinten ugyanis már nem partnerségi szervezetek, hanem önkormányzati társulások jönnek létre, melyekben csak önkormányzatok vesznek/vehetnek részt a törvény szerint. A korábban létrejött kistérségi szövetségekben a vállalkozások is jelen voltak, a gazdálkodó szervezetek is képviseltették magukat. E téren mindenképpen visszalépés az egyuittmúködés és a partnerség szempontjából a törvényi szabályozás alapján kialakított gyakorlat.

Gondot jelent mindez a törvényi szabályozásban és a gyakorlatban azért is, mert Nyugat-Európában éppen ezen a szinten jellemző leginkább a partnerség, a gazdasági és az önkormányzati szféra, valamint a civil szektor közvetlen együttmüködése. 
A terliletfejlesztési törvény lehetőséget teremt a kooperációra és a koordinációra, de ezzel mégsem készteti, föként nem kényszeríti az ágazatokat együttmúködésre, mivel nem tereli egy egyeztetési kényszerpályára a döntéseket. Országos szinten a minisztériumok képviselöi jelen vannak a döntéseknél, de területi szempontú kontrollnak az ágazati döntéseket nem kell elözetesen alávetni.

A terulletfejlesztés szempontjából az is fontos lenne, hogy a forrás felhasználást egyeztessék a partnerekkel, a területfejlesztés szereplöivel. Még inkább fontos a források koncentrált felhasználásának elve, mely alapján a területfejlesztés partnerei a saját forrásaikat is hozzárendelik a közős területfejlesztési céloknak. Mindez azért lenne szükséges, mert csak ebben az esetben valósitható meg az endogén forrásokra épülő, alulról építkező, decentralizált regionális politikai modellváltás. Az elmaradottság kezelése helyett/mellett ez képes csak a piac negatív hatásainak mérséklésére és az innováció ösztönzésére.

Magyarországon a regionális politika irányváltása megnőveli a népességnek azon körét, akiket közvetlenül is érint a területfejlesztési célelöirányzatok, az addicionális források és a projektorientált finanszírozás hatása és ezeknek a fejlesztésekre gyakorolt integratív jellege. (Horváth 1997) Erre a partneri egyưttmüködésben érdekelt szervezeteket és a területfejlesztés szereplöit már az Európai Unióhoz való csatlakozási folyamat kezdetén fel kellene késziteni és be is kellene vonni a csatlakozási folyamatok minden lépésébe, a mainál intenzivebb formában. Félö, hogy a gazdasági szervezetek a felkészités folyamatából kimaradnak, perifériára szorulnak, holott a kőzigazgatás (föként a központi közigazgatás) nem kezelheti saját ügyeként, a gazdasági szervezetek és a civil társadalom bevonása nélkưl ezt a folyamatot.

Lényeg a változás szempontjából, hogy a terulletfejlesztés a gazdasági és állami, önkormányzati szektor közötti partnerség formájában bontakozzon ki, de ahhoz a hatalom térbeli gyakorlásának rendje kell, hogy megszilárduljon és kialakuljanak az állami, közhatalmi decentralizáció stabil önkormányzati keretei.

\section{Sajátos konfliktusok a helyi kapcsolatokban}

$\boldsymbol{A}$ fejlesztések finanszírozását az elmúlt években sajátos módon befolyásolta, hogy az önkormányzati törvény elfogadása óta a fejlesztések megvalósitói a gazdasági lehetőségeikben korlátozott, döntéseikben szuverén önkormányzatok voltak. (ÁsZ, 1996. jún.) Gondot okozott, hogy a települési önkormányzatok nem, vagy csak esetenként szerveződtek olyan területi integrációkba, amelyek az infrastruktúra fejlesztés szempontjából optimálisak lettek volna. Valós probléma, hogy még ma is a vállalkozói szférával szemben kiszolgáltatottak az önkormányzatok, melynek következményei föként a késedelmes és nem megfelelö szerződésteljesitések során jelentkeznek, amikor is az esetek többségében, nem is élnek a szankcionálás lehetöségével az önkormányzatok. Elöfordultak természetesen olyan esetek is, amikor az önkormányzatok kártérítési igényt nyứjtottak be a felszámolás alatt álló vállalkozások ellen, amikor a vállalkozó levonult a még be nem fejezett beruházásokról.

Pécsett és Baranya megyében tapasztaltak alapján azt is elmondhatjuk, hogy nem megoldott a beruházások során az önkormányzatok és az intézményeik kőzötti 
Pécsett és Baranya megyében tapasztaltak alapján azt is elmondhatjuk, hogy nem megoldott a beruházások során az önkormányzatok és az intézményeik közötti viszony a kivitelezés és a minöség ellenörzését tekintve, ahol a vállalkozások az intézmények vezetöinek és munkatársainak észrevételeivel valójában nem is törődnek, hiszen a teljesítés igazolója és föleg a finanszírozója az önkormányzat illetve annak más intézménye.

A fejlesztések - elsősorban az infrastrukturális fejlesztések terén (telefon, gáz, benzinkutak, közmü beruházások, stb.) számtalan konfliktus és a kialakult monopol helyzetek (MATÁV, MOL, Gázszolgáltatók, kőzművállalatok akadályozták a helyi kapcsolatok kedvezöbb alakulását, de pl. a vízágazati beruházásoknál a múködtetés müszaki - gazdasági problémái (pl. kapacitás kihasználatlanság, fajlagos költségek alakulása, stb.) is rontották a fejlesztések finanszirozásának feltételrendszerét. A különböző szervezeti keretek között létrejött kapacitások és létesítmények jelentős hányada önkormányzatokon kívül eső tulajdonosi körbe került. A vagyon egy jelentős része - a vagyonértékesítésen kivül is - kikerült az önkormányzat korlátozottan forgalomképes vagyoni köréböl. A teljes jogi rendezettség esetében is legfeljebb részvényeket kapnak az önkormányzatok, amelyik vagyonkategória mobilizálhatóság és rendelkezési jogosultság szempontjából liberálisabb elbírálás alá esik. A megépült és a szolgáltatóknak kötelezỏen átadott gázhálózatok tekintetében feszültséget okoz, pl. az, hogy a közmüvagyonban megtestesülő önkormányzati pénzeszköz és a számottevő lakossági hozzájárulás összegszerüségében is meghaladja a jelenlegi szabályozás szerint juttatható részvényhányad névértékét és ráadásul még a részvények átadása is késett folyamatosan.

A jelentős lakossági összefogás révén létrejött közművagyon üzemeltetése tekintetében - bármilyen megoldást is választanak az önkormányzatok - a felmerülö többletköltségek közvetlenül vagy kőzvetve az igénybevevőket fogják terhelni. Mindezekkel a döntéseknél és az áralkuknál a tárgyalások során általában nem számoltak.

A vagyon értékesítése vagy a már privatizált társaságokba való bevitele pedig jövedelmezőségi okok miatt magában hordozza a jelentős állami támogatással és lakossági összefogással létrejött vagyon leértékelödésének a veszélyét. Az önkormányzatok ezek ismeretében arra számítottak, hogy az érintett gazdasági szervezetek, föként pedig a monopolhelyzetben lévő szervezetek majd intenzívebben bekapcsolódnak (mintegy kompenzálva a megszerzett elönyeiket az önkormányzatok és a lakosság irányába) a közösségi funkciók és a fejlesztések finanszírozásába. Ezek a reményeik egyelőre nem realizálódtak, ső́t a vizsgált térségben ennek a tendenciája sem igazolható. Félö, hogy a problémák egy részét a térségi koordináció is megérzi, mivel éppen ezeken a terulleteken volt erősebb a térségi koordináció, a területi válság kezelésére született kormányhatározatok által érintett megyékben különösen. (pl. gáz és telefonfejlesztés az Alföld - Tiszántúl térségében, de hasonlók a vízügyi ágazati fejlesztések a Dunántúlon). A fejlesztéseknél - éppen a kiemelt térségekben - nagyobb arányban tapasztalhattuk a fejlesztések forrásösszetételének megalapozatlanságát, a forrástervezés hiányosságait, a lakosság teherbíró képességének figyelmen kívull hagyását, a céltámogatási rendszer problémáit. Mivel a térségi feladatoknak nem volt valós 
felelöse, így a feladatok összehangolása is elmaradt, növelve ezzel az önkormányzatok és a lakosság kiszolgáltatottságát. Pl. a beruházási hitelek és a tartozások fejében az említett vállalatok megvették az önkormányzatoktól a beruházott vagyont, melynek révén még inkább növelhették monopolhelyzetüket.

Több beruházásnál (gázberuházások helyi konfliktusai) elöfordult, hogy az alvállalkozók által létrehozott teljesítmények ellenértékét sem fizették meg, holott elölegként az önkormányzatoktól a lakossági és a közületi hozzájárulásokat beszedték. Hasonló problémát okozott az önerős fejlesztések megszüntetése azután, amikor az önkormányzatok már a lakosságtól a hozzájárulásokat beszedték (pl. telefonfejlesztésre).

Országosan sok gondot jelentett a közvilágítás és a belterületi, valamint az összekötő utak építése a forráshiány miatt.

Különböző kezdeményezésekkel találkozhattunk a forrásbevonások növelése céljából e téren is. Mivel a kőzvilágitás fejlesztésére csak ủj településrészek kiépítése esetén kerủlt sor, a közvilágítási lámpahelyek és lámpák újra történő cseréjébe több településen is bevonta az önkormányzat a gazdálkodó szervezeteket. A szivességen, reciprocitáson alapuló forrásbevonás akkor múködött jobban, ha a gazdasági szervezetek neve valamilyen formában nyilvánosságra került (sajtóban és más tömegkommunikációban, vagy éppen a lámpatesteken egy-egy tábla hirdette a cégek nevét). Ezek a feltételek bizonyos esetekben üzleti érdekeket szolgáltak, míg más esetekben pusztán a helyiek közmegbecsủlésének jeleként értékelhetőek.

A reciprocitáson nyugvó helyi kapcsolatrendszerekben a mainál jóval nagyobb lehetőségek rejlenek a forrásbevonást illetően is. Természetesen illúzió lenne túl gyors változásokat remélni, hiszen a telepúlési és területi folyamatok alapvetően hosszú távú jelleggel bírnak. A folyamatot hosszabbá teszik a demokratikus fórumok is, melyeknek viszont elönye, hogy demokratikusabb, helyi társadalmi kontroll kapcsolódik a döntésekhez, éppen a helyi sajátosságok érvényesítése érdekében.

A helyi kapcsolatrendszerek sajátosságaként a reciprocitás súlyának szủkségszerū növekedési tendenciáját kell megemlíteni, ahol a telepủlési önkormányzatok a jövőben a mainál intenzívebb koordináló szerepet vállalhatnak és a gazdasági önkormányzatokkal (kamarákkal) sajátos munkamegosztást is kialakíthatnak.

A reciprocitást akadályozó tényezők napjainkban:

- a magas központi adóteher,

- a tulajdoni átalakulás bizonytalanságai,

- a privatizációban megjelenő érdekellentétek,

- az önállóságra törekvés és a kooperatív magatartás közötti konfliktus,

- alacsony hatékonyság,

- a jövedelemszerzés relatíve nagy időigénye a lakosság, a vállalkozások, gazdálkodó szervezetek esetében,

- a jövedelemelosztás és újraelosztás problémái,

- a szabad rendeltetésü ún. diszkrecionális jövedelmek relatíve alacsony hányada,

- társadalmi, politikai, szemléleti korlátok,

- az érdekegyeztetés mechanizmusainak és intézményrendszerének problémái. 
Mindezek mellett pozitív változások is tapasztalhatók voltak. Gondoljunk a civil szervezödések és az önkormányzatok kapcsolatára, a nonprofit szervezetek számának növekedésére, az üzleti szervezetek helyi aktivitására.

\section{Végül...}

Napjainkban megnött az igény a komplex településfejlesztési koncepciók készítése iránt, amely csak a helyi gazdasági és társadalmi élet szereplöinek együttmủködése révén realizálható. Megnő a helyi kapcsolatrendszerek szerepe akkor, amikor az alternatív fejlesztési elképzelések közötti választás, illetve a rangsorolás szükséges, hogy a választott, illetve a preferált alternatívának nagyobb legyen a megvalósulási esélye, éppen a helyi cselekvések révén, a gazdasági és a társadalmi élet támogatottsága mellett. A gazdasági szervezetek szerepénél és az önkormányzatokkal való együttmüködésnél figyelembe kell vennünk mindazokat a hatásokat, amelyek a piac individuális jellege és az önkormányzatok, föként a települési önkormányzatok müködésének közösségi jellege közötti konfliktusokból származnak, és sajátos módon befolyásolják az önkornányzatok kötelezỏ és önként vállalt feladatainak finanszírozási forrásait. Ahhoz, hogy a kullönböző koordinációs mechanizmusok együttes hatása a feladatok ellátásánál hatékonyságot eredményezzen, a települési önkormányzatok integráló szerepét is növelni kell. A gazdasági szervezetek, a gazdaság szereplöi felismerték, hogy az önkormányzatiság és a piacgazdaság keretei között már nem a közvetlen részvételi mechanizmusok játszanak szerepet, hanem a közvetett kapcsolatok jelentősége növekszik. Az átmenet időszakában persze minden szervezet és intézmény a saját belsỏ viszonyaival foglalkozott inkább, a kapcsolatrendszerek alakítása és intézményesítése a terület és településpolitika szempontjából sem volt az első helyen. Valószínü, hogy a következö időszakban a már kialakult intézményi és szervezeti rendszer elemei jobban keresik a horizontális kapcsolatokban rejlö lehetőségeket. Mindezeket ösztönzi a gazdasági kamarákról szóló törvény alapelve is, hiszen a törvény alapján a gazdasági önkormányzatok szerveződése is területi elven történik és feladataik egy része kapcsolódik is a terület és településpolitika, ezáltal pedig a helyi gazdaság alakításához. Úgy tünik, hogy a hellyi önkormányzatok és a gazdasági kamarák, illetve a gazdálkodó szervezetek kapcsolatrendszere akkor erősödik, ha az önkormányzatok kötelezö és önként vállalt feladatai között arányeltolódás következik be az önként vállalt feladatok javára. Az elmúlt időszakban ez éppen ellentétesen alakult, mivel a müködéshez szükséges forráshiányok a kötelezó feladatok finanszírozásának kényszerét jelentették településszinteken. Megállapíthatjuk, hogy a gazdasági szféra általában fontos eleme a helyi hatalmi viszonyoknak, de piacgazdasági viszonyok között csak akkor érvényesülhet a befolyása, ha szabályozott alapokon intézményesítése megvalósul a mellérendeltségen nyugvó partneri viszonyok alapján.

A gazdálkodó szervezetek és az önkormányzatok kapcsolatrendszerét sajátos módon meghatározza a gazdaság tulajdoni és szervezeti struktúrája.

A témakör vizsgálatánál elsősorban a 300 fő fölötti létszámot foglalkoztató, az ún. nagy gazdasági szervezetek kerülnek elótérbe, melyek az összes vállalkozások 1,4\%-át jelentik, bár igaz, hogy koncentrálják a tőke jelentős részét. Ugyanakkor a 
szervezeteknél a felhalmozott tudás, szakértelem, szellemi tőke hasznosítása és az információk felhasználása is fontos a település és a térség fejlödése szempontjából. A kapcsolatrendszereket célszerü formalizált együttmüködési megállapodásokban rögzíteni és intézményesíteni annak érdekében, hogy a fejlesztési célok kiválasztása ne külsődleges impulzusok alapján történjen, hanem azokkal azonosuljon a helyi társadalom és gazdaság minél több szereplöje.

\section{Irodalom}

Az Állami Számv vőszék Tájékoztatója az onkormányzatok pénzügyi egyensúlyi helyzetének ellenörzési tapasztalatairól. Önkormányzati Tájékoztató, 1997/1.

Hegyesi Gábor (1991) Integrációs modellek és nonprofit szektor Esély l. sz.

Horváth Gyula (1997) A magyar regionális politika változása a XX. század végén Magyar Tudomány 1.

Kuti Éva - Marschall Miklós (1991) Ki finanszirozza a kultúrát, miért és hogyan? Társadalmi Szemle 3.

László Mária (1997) Az onkormányzatok gazdasági eszkozrendszere PhD. dolgozat, Kézirat, JPTE

Kozgazdaságtudományi Kar 150. o.

Pálné Kovács Ilona (1997) A teruletfejlesztési tanácsok mükődésének tapasztalatai Kézirat, OTKA 7047. Az onkormányzatok gazdasági eszkozrendszere Témavezető: László Mária

Pécs város marketingfejlesztési koncepciója 1997. JPTE TTK Turizmus Tanszékcsoport, Kézirat, Témavezetö: Aubert Antal

Savas E. S. (1992) Privatizáció - Hogyan vonuljon ki az állam a gazdaságból?

\section{PUBLIC-PRIVATE PARTNERSHIPS IN FINANCIALNG PUBLIC SERVICES}

\section{MÁRIA LÁSZLÓ}

In the theoretical studies of economics, private enterprises in financing public services are considered either as additional resources to governmental expenses or as entities investing into human capital for improving their competitiveness. The environmental approach puts enterprises into the context of the system of social, economic and institutional relations that have a considerable impact on economic decision-making process. In this way, enterprises have an important part in social harmony and economic development.

Since financial resources of local governments for the operation and development of public services are scarce, local enterprises are considered as potential partners of authorities in such activities. Collaboration between local actors should result a more efficient service system of a higher quality. Such projects reflects the transition process in the environment of the Hungarian local government system, such as structural and spatial changes in the economy, social and regional differentiation and conflicts that effected relations of the public and private sector as well. To manage such problems, regional development policies should consider not only public institutions and authorities but also private enterprises as actors of spatial development. For this purpose, decentralised and operational framework of territorial administration must be established. 
In the transition period, regional development projects were implemented by sovereign local governments having scarce financial resources. They received no significant support from large scale service companies (enjoying the status of monopoly) and were often exposed to the unfair business conduct of private contractors. Such conflicts should be eliminated through co-operation between the public and private sectors resting on reciprocity. The first steps towards broadening such "horizontal" relations must be the integration of interests and purposes of enterprises into local development strategies and defining the conditions of collaboration in formal contracts. In this way, development policies of the local government will be supported widely. 